UDC 72(092)(477.83)

LEVYK BOHDAN,

Regional Scientific-Educational center at Lviv Polytechnic National University

e-mail: levykbs@gmail.com,ORCID:0000-0001-5100-0834

\title{
LVIV ACHIEVEMENTS OF ARMENIAN JULIAN OKTAWIAN ZACHARIEWICZ
}

\begin{abstract}
The path of life of Julian Oktawian Zachariewicz (17.07.1837 - 27.12.1898), talented Armenian architect, who dedicated himself to the scientific and pedagogical activities in Lviv Polytechnic National University, then Imperial-royal polytechnic school, was traced within the framework of the study of the topic "Prominent figures in culture and development of Lviv". Having founded the Galician School of Architecture, he implemented his projects in administrative and private buildings of Lviv and crown land of Galicia and Vladimiria (Lodomeria), which remain a decoration and an example of architectural mastery until now. As part of the study, the author introduces to the science newspaper publications of past years (pre-Soviet period, September 1939), dedicated to the solemn dates associated with the name of the prominent architect. The author concludes that Julian Oktawian Zachariewicz's biography can be considered as the historical source of research on the development of "neo" style architecture in the administrative, sacred and private urban buildings of Lviv of the Austro-Hungarian period (1872-1918). Despite the fact that Zachariewicz himself did not focus on his nationality, his relation to the Armenian diaspora, the Armenian ethnic group and Armenian Christianity reflected on his work and this aspect should be researched in the future.
\end{abstract}

Keywords: Zachariewicz Julian Oktawian; Technical Academy on Lviv; Lviv High Technical School; the Tsisar-Royal Polytechnic School; Lviv Polytechnic National University.

\section{Introduction}

National, cultural, religious (confessional) identification and assimilation of individuals in different types of states has always been a scientific problem for which scholars failed to find (establish) predicted laws. This paper gives an example of the complete (Austrian) assimilation of the outstanding architect, of Armenian descent Julian Oktawian Zachariewicz in the multifaceted multi-ethnic and multilingual environment of Galicia and Volodymyr (Lodomeria), the largest royal province of the Austro-Hungarian Empire.

As it is known, the representatives of the Armenian nation settled around the world. They found their place in Galicia as well, including in the medieval Lviv. Here they settled in a compact community - a colony, which was traditional for that time. This mode of life helped to preserve national identity. Until now, there is the Armenian street ("vulytsia Virmenska") in Lviv, in its northern part, which holds the historical heritage and the facts of staying of this ethnos on the Galician land. A sacral building - the Armenian Cathedral - is located here. This part of the municipal land belonged to the Armenian community and was called the Armenian Quarter.

The beginning of the history of the Armenian diaspora dates back to the $13^{\text {th }}$ century, when, as a result of the Mongol-Tatar invasion, the Armenians lost their homeland. In 1239, the Khan Alp Aslan destroyed the capital of the Armenian state Ani, which triggered the first emigration wave of Armenians. During the $13^{\text {th }}$ and $14^{\text {th }}$ centuries, the princes and knights left Armenia and had to hire to serve
Galician and Galician-Volyn princes, Daniel of Galicia (Danylo Halytskyi), and his son Lev Danylovych. The Armenian merchants, who also emigrated and quickly took over the dominant position in this area, became merchant intermediaries between East and West owing to their foreign language skills.

The first apostolic Armenian churches in Lviv are associated with the names of the Most Holy Mother of God and Saint Gregory the Illuminator. Armenians were peaceful and benevolent, but quite closed, which was due to the complexity of their language and spelling, traditions, and culture. Subsequently, settled merchants turned into wealthy petty bourgeois, and some of them managed to buy estates with the land. In the $14^{\text {th }}$ century, the Armenian colony in Lviv was the third in Europe, after Venice and Amsterdam. In 1364, Lviv became the center of the Armenian-Gregorian bishopric.

In the $14^{\text {th }}$ century, after the loss of complete independence of Armenia and the capture of the Crimea by Turks in 1475, the second wave of emigration to the Galician lands started. The Armenian communities of Tysmenytsia, Sniatyn, Stanislaviv, Brody, Berezhany, Kuty, Zholkvy and Zolochev were much smaller than the communities in Lviv and Kamianets of Podillia. The Polish kings equalized the rights of the Armenians with the Poles, having given them the right to self-government and own court. Polish Sejm conferred nobility on some of the Armenian representatives; they gained noble status and joined the aristocratic estate with the right of their own 
coat of arms. The ennobled Armenians were usually large landowners ${ }^{1}$.

In 1630, the Armenian Archbishop Mykola Torosovych transferred to a permanent union with the Roman Catholic Church, which accelerated the Polonization and Catholization of the Galician Armenians (Kapral, 2003: 178-190). In the $17^{\text {th }}$ century, more than 2,000 Catholic Armenians lived in Lviv; in the next century, their number decreased by ten times, and at the beginning of the $20^{\text {th }}$ century, only the Armenians with polonized surnames remained. The Lviv Archeparchy of the Armenian Catholic Church sui iuris consisted of about 3,500 believers, 20 clerics, and 15 churches. The Armenians of Lviv had their schools, libraries, hospitals, printing houses, metropolises, and theater. The Armenian historian and writer Simeon Dpir Lehatsi (Lthugh), pointed to charitable (philanthropic, pious, financial and moral assistance) activities in the Armenian district of Lviv.

In the second half of the $17^{\text {th }}$ century, Moldavian, Romanian and Crimean Armenians came to Galicia and joined the already existing communities in Lviv, Kuty, Horodenka. After the adoption of the Union, a total assimilation process began. In 1766, Polish king Stanisław August of Poniatowski family, confirmed the rights of the Armenians. It was during his reign, when the largest ennoblement was held, up to 800 people. Armenians lost their language.

In the pre-Austrian period (1772), in Lviv, city cemeteries were located around the temples (churches, kościółs, synagogues). The Armenian Cathedral of the Assumption of Mary was not an exception. The Armenian cemetery near the cathedral still preserved the grave slabs, where the Armenian inscriptions changed to Latin, and then to Polish as time went on.

The Armenians of the medieval city of Lviv were engaged in trade, were excellent interpreters, which was the main thing for close and long-term cooperation with foreign merchants. The Armenian community had its own justice and assembly; they organized its own self-government. However, time and the surrounding urban environment prompted their assimilation: Polish, Austro-Hungarian, again Polish, Soviet, and Ukrainian.

In 1340-1349, Lviv was conquered by the Polish king Casimir III and was part of Poland until its first partition in 1772, when the Austro-Hungarian Empire acquired Galicia. Prior to this, in 1630, the Armenian Bishop Mykola Torosovych entered Catholicism, therefore the Armenian community of the $17^{\text {th }}$ century spoke good Polish, had mixed marriages, changed their surnames to the Polish tradition. During this period, about 2,000 Armenians lived in Lviv.

In 1880, there were 3,872 Armenians in Galicia and Bukovyna, and in 1910, 1,392 people in Galicia and 657 in Bukovyna (Monolatiy, 2012). The Armenian (Gregorian) diocese of Lviv in 1890 has 4,000 Armenian Catholics, served by 19 priests. Among the well-known representatives of the Armenian ethnic group were the families Passakass, Khuel, Romaszkan, and Shadbei.

The Armenians, by their Christian faith, were more close to two Slav peoples, Ukrainians and Poles, than to the Jews who were kept closed and aside. At the end of the $19^{\text {th }}$ century, there were chasms between Poles and Jews, Ukrainians and Poles. Lviv became the epicenter of three

\footnotetext{
${ }^{1}$ During the Polish-Lithuanian Commonwealth, the classical ennoblement (according to the decision of the Sejm) was conferred on 1,600 people.
}

nationalisms (Ukrainian, Polish and Jewish) and two liberation movements (Ukrainian and Polish). The Armenians managed to stay away from this political and cultural struggle. The Austro-Hungarian Empire entrusted to "sew up" the polytheistic and multi-confessional environment in Galicia to the governors appointed by the emperor from the representatives of the Polish aristocrats, who were counts and princes. The representative body of the emperor of the Galician Crown Region was the Diet of Galicia and Lodomeria (currently the premises of the Ivan Franko National University), representing the interests of 8 million people, accounting for $28 \%$ of the total population of the Austro-Hungarian Empire (census of 1910). The share of Ukrainians as of 1900 was 3 million (63.5\%). There were 870 thousand Poles, 613 thousand Jews, and 60 thousand Germans in the province. The Czechs, Armenians and Russians were small groups. According to religious preference, the ethnoconfessional composition of 1910 was divided into Roman Catholics - 3,731,569, Greek Catholics - 3,381,105, Jews - 871,895, Protestants - 37,698, Orthodox - 2,818, other confessions - 609 (Hrytsak, 2006). According to statistics, as of 1910, 104 Armenians were officially registered in Galicia. In the city of Lviv, according to the census of 1910 , the Armenians were not listed at all, although according to the census of 1900 , there were 231 people living in Lviv (Kysilevskyi, 1965: 4648). There were 311 Catholic Armenians, and 31 Christian Armenians in Chernivtsi (Bukovyna). It was in Bukovyna that the Armenian ethnos in the middle of the $19^{\text {th }}$ century owned 70-80 villages and land, which was one third of all land in the region. At the end of the $19^{\text {th }}$ century, the Armenian colonies ceased to exist.

As of today, a comprehensive, systematic study of the Armenian community of Lviv metropolis steel waits for its historian. Most scholars gave attention to specific prominent representatives who made a significant contribution to the development of science, culture, and medicine. Continuing this tradition, we define the purpose of this article to be the biography of the outstanding representative of the Armenian community of Lviv, professor of architecture, the founder of the Galician school Julian-Oktawian Zachariewicz.

\section{Theoretical basis}

Biographies are an integral source of historical research. The Russian scientist I.F. Piotrovskaya in her work "Biography Studies: Introduction to Science ..." states that "biography studies are considered as a special science of the system of historical sciences. Like other historical sciences, it studies the past of humanity and has a lot of research methods in common with them. The essential difference is in the object of study. Other historical sciences study the results of people's activities and "public consciousness," and biography studies inquire directly an individual in history, in all manifestations of its existence, including its psychic world. This is the science of understanding the lives of specific people involved in all sectors of human activity. Like history, which consists primarily of historical knowledge and besides it - the theory and methodology of historical research, biography studies as a special historical science include not only the development of theoretical problems of science itself and the laws of human life, but also the actual biographical knowledge: the drawing up of biographies" (Piotrovskaya, 2010: 12-13).

The drawing up biography of Julian Zachariewicz was specifically undertaken by Ukrainian and Polish re- 
searchers - authors of collective monographs, encyclopedic and bibliographic reference books, and newspaper publications (Yavorskyi, Blazhivskyi, 2001; Vasylenko, Voytovych, Hubenko (compiler), 2004; [Pro Yuliana Zakharievycha], 2008; Bevz, Biryulov, Bohdanova, Didyk and other, 2008; Bobalo, Zahorodniy (ed.), 2009; Rudavskyi (ed.), 2004). Among them prof. Yu. Biryuliov and his monograph "Zakharevychi" should be especially distinguished (Y. Biryulov insists on such a transliteration), in which the author focuses on the architectural achievements of father and son Alfred Zachariewicz (Biryuliov, 2010). Among Ukrainian researchers of educational, scientific and creative activity of prof. Julian Zachariewicz the following may be mentioned: M. Butsko (Butsko, 1988; Butsko, Kyparenko, 1994; Butsko, 1994), O. Zhuk (2002; 2004; 2004: 141-145; 2006; 2007: 50-53; 2008; 2008: 216 218), B. Cherkes (Cherkes, 1994; Cherkes, Zhuk, 2007; Cherkes, 2007), T. Klymenyuk (2000), M. Kubelik (1996), I. Lonkevych (1998), R. Lypka (2000), Yu. Petrovska (2011), Ye. Sadovska (2002), and I. Melnyk. Polish scientists Popławski Z. (1992), Zajączkowski W. (1894), German engineer-historian Khenryk Dytkhen (2015) dedicated their researches of Lviv Polytechnic University and mentioned a significant contribution of professor, head of the chair of building and architectural constructions, history of architecture, Rector of the Technical Academy in Lviv, architect Julian Zachariewicz. We found newspaper publications of the past years (pre-Soviet period, September 1939), dedicated to the special occasions associated with the name of the famous architect Julian Zachariewicz (S.p. Zachariewicz Julian Oktawian: nekrolog, 1899; Odezwa: [pro vstanovlennya byusta Yu. Zakharievycha u holovnomu korpusi Lviv. politekhniky], 1909; O budowie gmachów c. k. Szkoły Politechnicznej we Lwowe, 1877; Uroczyste odsłonięcie pomnika ś. p. [świętej pamięci] Juliana Zaharjewicza, 1910).

\section{Results and discussion}

Julian Zachariewicz was born on July 17, 1837 in Lviv. His father, Georgiy, came of an ancient Armenian bourgeois family. Mother was from the Grosman family. By his religion, Zachariewicz belonged to the Lutheran community, and was an Evangelical Protestant. He started his education in the real school of the Lviv Technical Academy, which was ranked the eighth after the similar academic higher education schools in Paris, Glasgow, Prague, Vienna, Karlsruhe, Dresden and Stuttgart. Having graduated from gymnasium and studied at the construction department; he received a technical engineer degree. The education process at the Lviv Technical Academy was conducted in German and completely copied the program of the Polytechnic Institute in Vienna. In 1858, Julian Zachariewicz completed his studies at the Polytechnic Institute in Vienna, where he simultaneously participated in the restoration of St. Stephen's Cathedral. In Vienna, he had an internship at the architectural bureau of Leopold Ernst. Upon his graduation from the Polytechnic Institute in Vienna, he stayed in Vienna and worked at the General Directorate of Railway Construction. From 1860 to 1865 he worked at the private railway of Karl Ludwig.

In 1865, Julian Zachariewicz lived in Chernivtsi, where he conducted the design and construction of railway station buildings. By that time, from September 1, 1866, a railway line of $267 \mathrm{~km}$ long was built from Lviv through the city of Khodoriv-Stanislaviv-Kolomyia to Chernivtsi. Julian Zachariewicz was a co-author of project of the station in lași in the Moresque (Mediterranean) neo-Gothic style. At that time, Ludwig Wierzbicki was the main designer of the railway palaces, who built in arcade style (historicism). The number of floors of the building of the railway palaces depended on the greatness of the city. Thus, the Chernivetskyi railway station in Lviv had 3-4 floors, and the railway station buildings of Stanislaviv and Chernivtsi had 2-3 floors.

In Chernivtsi, Julian Zachariewicz received the position of head of the railway transportation in the Austro-Romanian direction. Here he married Danish Anna Josefa David (1841-1874). They had three children, two sons: Viggo and Alfred, and daughter Anna. The wife died in childbirth in a private villa in Lviv at 9 Kameniariv Street, at the corner of Tekhnichna Steet near Jesuit park (now Ivan Franko Park). Zachariewicz completed his own house a year before the construction of the main building of the Lviv Polytechnic National University, in 1873.

On April 12, 1872, the governor of Galicia and Lodomeria Count Agenor Goł uchowski appealed to the Emperor of Austria-Hungary Franz Josef I to allocate funds for the construction of the Polytechnic School in Lviv. His request was met and the emperor allocated for the construction from the state treasury 1.3 million Austrian forints (guldens) which were still called zoloty rynsky in Galicia. The previous project was developed by Edmund Sticks in 1867-1868 with an attachment to the Castrum Square (now the district of Virmenska and Krakivska streets crossing). Zachariewicz began his design in 1872 near the existing Novyi Svit Street (today, it is Stepan Bandera Street) on lands belonging to Countess Maria Fredro. Already at the end of the same year, he finished the project of the main and chemistry buildings (building size $45 \times 38 \mathrm{~m}$ ) in the neoRenaissance style. In 1873 , his project was approved by the Government of Galicia and Volodymyr (Lodomeria), as well as the imperial Ministry of Education.

Count A. Gołuchowski allocated money for J. Zachariewicz's trip to Europe to study the modern European architectural practice, having allowed him a month-long vacation. Julian Oktawian visited Vienna, Zurich, and Munich, where he learned the best projects of administrative buildings.

According to the project of Julian Zachariewicz, the main building of the Lviv Polytechnic National University is rectangularly shaped; it is $113 \times 68 \mathrm{~m}$ in size, and has two inner courtyards. The construction started on April 1, 1874. There were up to 600 craftsmen working daily, including 240 wallers, 30 masons, 40 carpenters, and 300 assistants. The stone was brought from the quarries of Terebovlia and Dempa. Gypsum was bought at the Lviv factory of Josef Franz. Plumbery and stove heating were made by Viennese specialists. On October 1, 1877, the construction of the main facade was completed (Sadovska, 2002). It should be noted that the year before, in 1876, the construction of the chemistry building of the Technical Academy was completed, which was also designed by Julian Zachariewicz. The Technical Academy in Lviv received the full rights of the Austrian university. On October 7, 1877, on the territory of Austria-Hungary, a demonstration of a telephone conversation between the assembly hall of the main building and room 101 of the chemistry building was held at the Technical Academy in Lviv.

In 1871, Julian Oktawian Zachariewicz was invited to become the head the Chair of Construction (Architecture) at the Technical Academy in Lviv, which from 1877 was renamed Polytechnic School. At first, he worked as professor ordinarius. He had 59 hours as a weekly load with an assistant, which evidences his enormous working 
efficiency. In the same year, he received a professor degree. He served as a dean of the Construction (Architecture) Department three times (1872/73, 1876/77, 1880/ 81 ), and was elected as a rector twice in 1877-1878 and 1881-1882 academic years.

In 1875 , he began to form his own group of studentsarchitects. He introduced annual open exhibitions of diploma projects of his students (Biryuliov, 2010).

On November 15, 1877, during his inauguration prof. Julian Zachariewicz opened the academic year in a new building of the Polytechnic School with a speech "Art in the Service of Technology". On February 14, 1877, both buildings were solemnly blessed by the Lviv Metropolitan of the Greek Catholic Church Joseph Sembratovych, and the bishop of the Roman Catholic Church Grzegorz Romaszkan. The blessing was attended by marszałek of the Galician Sejm Ludwik Wodzyński and the governor of Galicia and Lodomeria Alfred Józef Potocki. These two academic places could admit up to 300 students at a time. The main building originally was white, then it was recoloured red; in 2003 the initial white color was returned to the building.

On October 8, 1877, in accordance with the Tsisarian decree, the Technical Academy was renamed the Higher Technical School, which received the status of AustrianHungarian academic school. The board of professors changed the name to Tsisar-Royal Polytechnic School at its discretion.

In the same year of 1877 , prof. J. Zachariewicz married for a second time with Ludwiga Gromadzińska; they had two children: daughter Helena and son Julian-Edwin.

In 1877, at the Higher Technical School in Lviv, Department of Construction (Architecture) was established upon the initiative of prof. Julian Zachariewicz. In 1882, 28 students studied there. In 1883, Polytechnic School received full legal recognition throughout the Germanspeaking region (Khenryk Dytkhen, 2015). In 1894, there were three chairs at the Construction Department. One of them, which specialized in the architectural forms, architecture aesthetics, designing and railway architecture was supervised by the professor himself. It is obvious, it was J. Zachariewicz who initiated long-term and fruitful cooperation between the academic institution and the railway administration. The second chair of architectural constructions, estimates and construction legislation was headed during 1876-1901 by Gustav Bisanz, a former assistant of Julian Zachariewicz. Prof. Bisanz was also elected twice as the rector in 1888-1889 and 1898-1899. The third chair of drawing and modeling was established in 1873; it was headed until 1899, until the day of his death, by professor ordinarius, close associate and partner Leonard Marconi, recognized master of sculptural design of administrative buildings of Lviv.

On September 13,1880, the main building of the Technical School was visited by the Austrian-Hungarian Tsisar Franz Josef I. During his visit, he attended morning prayer in the nearby Church of St. Magdalen and made a 20-minute review of the newly built premises. The Tsisar donated to the Polytechnic School 11 drawings showing the technical achievements of mankind, which were subsequently performed by students of the Polish artist Jan Matejko using rough copies (draft sketches) of the latter, and an honorary title for Julian Zachariewicz himself. Considering the merits to the city and love for Lviv, the professor received a name affix to his last name Zachariewicz-Lwigród. Along with prof. Ivan Levynskyi and Alfred
Kamienobrodzki, he was the pioneer in establishing complex architectural and construction companies in Lviv. Having served as a rector of the University in 1888, prof. Zachariewicz proposed the idea of constructing a Technical House, an "academic house" (student hostel) for students. In 1892, Lviv authorities allowed raising donations for the construction of an "academic house". Prof. Ivan Levynskyi and prof. Julian Zachariewicz presented a land lot at Kastelivka purchased at their own expense for the construction of this student hostel. The committee on the construction of the student hostel received a loan from the bank, with a pledge and a guarantee of return given by prof. J. Zachariewicz and prof. I. Levynskyi. In 1895, the student hostel was built on Issakovych street (today, it is Horbachevskyi Steet) (Petrovska, 2011).

In 1890, the family of Zachariewicz moved to Kastelivka, a new, yet unbuilt district of Lviv, which was quickly built up by private villas. Today, at the address 14-a Metrolohichna Street, a private villa called "Julietka" may be found, which was built by Julian Zachariewicz in 1891-1893 upon his own project.

In Lviv, prof. Zachariewicz left many of his implemented projects, including the main and chemistry buildings of the Lviv Polytechnic National University, the Galician Savings Bank (today, the Institute of Ethnography), the water tower on the Wystawa Krajowa, the Franciscan monastery complex at the address 41 Lysenko (Kurkova) Street. He was engaged in the restoration and reconstruction of architectural monuments of Lviv (temples of John the Baptist on the Staryi Rynok Square and the Church of Our Lady of the Snow). Along with these projects, the private houses should be mentioned: private villas on NechuiLevytskyi Street, number 20 (villa "Maria") and number 23, and on Chuprynky Street, No. 5, 7, 9, reconstructed monastic complex of barefoot carmelites, private villas on Metrolohichna Street, No. 2, 4, 6, 8, 10. On the corner of O. Novakivskyi and Lystopadovyi chyn Streets, there was a private house of Jan Styka, which was subsequently purchased by the Metropolitan of UGCC Andrey Sheptytsky in 1911 and transferred to the property of Ukrainian artist Oleksii Novakivskyi.

Julian Zachariewicz collected works of Ukrainian applied art (Hutsul ceramics, vytynanky).

He died in the morning of December 27, 1898 in Lviv in his villa "Julietka" in Kastelivka. He is buried at Lychakiv cemetery-museum, field number 55 . He designed a tombstone on his own grave several years before his death. His family coat of arms depicted a lion with a hexagonal star in his paw and a knight with a raised sword.

In 1910, the portrait sculpture of the prof. Julian Oktawian Zachariewicz was installed in the main building. The sculptor is Julian Bełtowski (Odezwa: [pro vstanovlennya byusta Yu. Zakharievycha u holovnomu korpusi Lviv. politekhniky], 1909: 13, 122). In 1992, in honor of prof. Zachariewicz one of the streets of Lviv was named, which is located near the territory of the Lviv Polytechnic National University. In Soviet times, the name of the street was changed to Arkhitektorska. In independent Ukraine, the street in tribute to prof. Zachariewicz appeared in Kastelivka.

\section{Conclusions}

The biography of architect Julian Zachariewicz may be presented as a historical source for the study of the development of neo-style architecture in the administrative, sacred, and private urban buildings of Lviv during the 
Austro-Hungarian period (1872-1918). By studying his creative, scientific, and pedagogical personality, we may not only observe the harmonious professional growth of a talented Galician student of Armenian origin in an age of the Habsburg monarchy, but we also make broader conclusions about his connection with the Armenian diaspora, the Armenian ethnic group, and Armenian Christianity. Due to the influence of polyethnic Lviv and the powerful influence of imperial ideology, Julian Zachariewicz was fully assimilated into the Austro-Hungarian society. Having been a Protestant by religious preference, he did not identify himself according to national affiliation. This aspect of personal life of prof. Julian Zachariewicz remains open for further inquiries.

\section{REFERENCES}

Bevz, M., Biryulov, Yu., Bohdanova, Yu., Didyk, V., Ivanochko, U., Klymenyuk, T., Kovalchuk, Kh., Kryvoruchko, Yu., Linda, S., Maksymyuk, T., Mykh, R., Mohytych, R., Okonchenko, I., Petryshyn, H., Posatskyi, B., Rybchynskyi, O., Svarnyk, I., Frankiv, R., Cherkes, B. (2008). Arkhitektura Lvova. Chas i styli XIII-XXI st. Lviv: Tsentr Yevropy, S. 51, 52, 140, 247-249, 256, 266, 267, 290, 294, 300, $303,306,310,318,346,347,349,351,353,354,356,375,391$, 392, 396, 407, 411, 457, 477 (In Ukrainian).

Biryuliov, Yu. (2010). Zakharevychi tvortsi stolychnoho Lvova. Lviv: Vydavnytstvo "Tsentr Yevropy", 336 s. (In Ukrainian).

Butsko, M. (1988). Yulian Zakharevych: [rektor Lviv. politekhniky (1877-1878, 1882-1883 rr.)]. Rad. student. December 31 (№38). S. 4. (In Ukrainian).

Butsko, M. (1994). Zakharevych Yulian Oktavian. In: Butsko, M. I. Vidomi vcheni Derzhavnoho universytetu "Lvivska politekhnika". 1844-1994: biohr. dovid. Lviv: Vyd-vo Derzh. un-tu "Lviv. politekhnika", S. 58-59 (In Ukrainian).

Butsko, M. I., Kyparenko, V. H. (1994). Derzhavnyy universytet "Lvivska politekhnika" 1844-1994. Lviv: Vyd-vo Derzh. un-tu "Lviv. politekhnika", Iz zmistu: pro Yu. Zakharievycha. S. 5, 9, 10, 13, 19, 90. (In Ukrainian).

Cherkes, B. (1994). Osnovopolozhnyk: [pro zasn. arkhitektur. shkoly Lviv. politekhniky, rektora (1877-1878, 1881-1882 rr.) Yuliana Zakharievycha]. Lviv. politekhnik. May (spets. vyp.). S. 6 (In Ukrainian).

Cherkes, B. (2007). Vstup. Zvidky i kudy: arkhitektura Halychyny XIX-XX stolit: [pro Yu. Zakharievycha]. In: Cherkes, B. S. (ed.). Arkhitektura: zbirnyk naukovykh prats. Lviv: Vyd-vo Nats. un-tu "Lviv. politekhnika", S. 19-44 (In Ukrainian).

Cherkes, B. S., Zhuk, O. K. (2007). Yulian Zakharievych - osnovopolozhnyk Ivivskoyi arkhitekturnoyi shkoly. In: Cherkes, B. S. (ed.). Arkhitektura: zbirnyk naukovykh prats. Lviv: Vyd-vo Nats. un-tu "Lviv. politekhnika", S. 163-167. (Visnyk / Nats. un-t "Lviv. politekhnika"; № 585) (In Ukrainian).

Hrytsak, Ya. (2006). Prorok u svoyiy vitchyzni. Franko ta yoho spilnota (1856-1886). Kyiv: Krytyka, S. 545 (In Ukrainian).

Kapral, M. (2003), Natsionalni hromady Lvova XVI-XVIII st. (sotsialno-pravovi vzayemyny). Lviv: LNU im. I. Franka, Lvivske viddilennya Instytutu ukrayinskoyi arkheohrafiyi ta dzhereloznavstva im. M. S. Hrushevskoho NAN Ukrayiny. S. 178-190 (In Ukrainian).

Khenryk, Dytkhen (2015). Lvivska politekhnika u Lvovi: istoriya tekhnichnoho universytetu u bahatonatsionalnomu seredovyshchi. Shtuthart (In Ukrainian).

Klymenyuk, T. (2000). Pedahohichna diyalnist Yu. Zakharevycha, tradytsiyi Lvivskoyi arkhitekturnoyi shkoly. Tekhnichni visti / Ukrainske inzhenerne t-vo. № 1(10), 2(11). S. 86-91 (In Ukrainian).

Kubelik, M. (1996). Das k.k. Polytechnische Institut in Wien zur Zeit des Studenten Julian Zachariewicz. In: Cherkes, B., Kubelik,
M., Hofer, E. (ed.). Arkhitektura Halychyny XIX-XX st.: vybr. materialy mizhnar. symp., May 24-27, 1994, Lviv: prysvyach. 150-richchyu zasnuvannya Derzh. un-tu "Lviv. politekhnika". Lviv: Vyd-vo Derzh. un-tu "Lviv. politekhnika", S. 89-98.

Kysilevskyi, V. Yu. (1965). Statystychnyy opys Halychyny u 1840 rotsi. Ukrayinskyy istoryk [Myunkhen]. № 1-2. S. 46-48 (In Ukrainian).

Lonkevych, I. (1998). Spoviduvav i tvoryv krasu: [pro rektora Lviv. politekhniky Yuliana Zakharievycha]. Audytoriya. December 18-30 (Num. 45-46). S. 7 (In Ukrainian).

Lypka, R. (2000). Lvivska arkhitekturna shkola - yiyi rol ta etapy rozvytku: [pro arkhitektur. f-t Lviv. politekhniky, Yu. Zakharievycha]. Tekhnichni visti / Ukrainske inzhenerne t-vo. № 1(10), 2(11). S. 99-110 (In Ukrainian).

Monolatiy, I. S. (2012). Halytsko-bukovynski syuzhety $v$ istoriyi virmenskoyi diaspory Habsburzkoyi monarkhiyi: sproba (re)konstruktsiyi. Prykarpatskyy natsionalnyy universytet imeni Vasylya Stefanyka. Retrieved from: http://ekmair.ukma.edu.ua/ bitstream/handle/123456789/7169/Monolatiy_Halytsko bukovynski_syuzhety.pdf?sequence=1\&isAllowed=y (In Ukrainian).

O budowie gmachów c. k. Szkoły Politechnicznej we Lwowe (1877). Dźwignia. № 5. S. 35-36 (In Polish).

Odezwa: [pro vstanovlennya byusta Yu. Zakharievycha u holovnomu korpusi Lviv. politekhniky] (1909). Czas. Techn. Rocz. 27, № 2. S. 13, 122 (In Polish).

Petrovska, Yu. (2011). Syntez mystetstv u tvorchosti arkhitektoriv Lvivskoyi arkhitekturnoyi shkoly zlamu XIX-XX st.: [pro Yu. Zakharievycha, I. Levynskoho, T. Taliovskoho, V. Sadlovskoho, T. Obminskoho]. Heodeziya, arkhitektura ta budivnytstvo: materialy IV Mizhnar. konf. molodykh vchen. GAC-2011, November 24-26. 2011. Lviv: Vyd-vo Lviv. politekhniky, S. 32-35 (In Ukrainian).

Piotrovskaya, I. D. (2010). Biografika: vvedenie $v$ nauku $i$ obozrenie istochnikov biograficheskikh svedeniy o deyatelyakh Rossii 1801-1917. Izd. 2-e, ispr. i dop. St. Petersburg: Petropolis, 384 s. (In Russian).

Politechnika Lwowska 1844-1945 (1993). Wrocław: Wydwo Politechniki Wrocławskiej, S. 19-22, 29, 51, 139, 143-144, 155, 173, 194, 195, 202, 203 (In Polish).

Politechnika Lwowska: jej stan obecny i potrzeby (1932). Lwów, S. 108-109 (In Polish).

Popławski, Z. (1992). Dzieje Politechniki Lwowskiej, 18441945. Kraków: Zakł. Nar. im. Ossolińskich, S. 54, 58, 62, 66-68, 72, 73, 77, 96, 97, 102-105, 111, 116, 117, 302, 306 (In Polish).

[Pro Yuliana Zakharievycha] (2008). Audytoriya. October 2329. (Num. 30). S. 4 (In Ukrainian).

S.p. Zachariewicz Julian Oktawian: nekrolog (1899). Czas. Techn. Rocz. 17, № 1. S. 1-3 (In Polish).

Sadovska, Ye. Ya. (2002). Yulian Oktavian Zakharievych restavrator kostioliv. In: Cherkes, B. S. (ed.). Arkhitektura: zb. nauk. pr. Lviv: Vyd-vo Nats. un-tu "Lviv. politekhnika", S. 122-127. (Visnyk / Nats. un-t "Lviv. politekhnika"; № 439) (In Ukrainian).

Uroczyste odsłonięcie pomnika ś. p. [świętej pamięci] Juliana Zaharjewicza (1910). Gazeta Lwowska. 13 wrześ. (№ 207). S. 4 (In Polish).

Yavorskyi, V., Blazhivskyi, K. (2001). Istoriya khimichnoyi, khimiko-tekhnolohichnoyi osvity i nauky u Lvivskiy politekhnitsi (1844-1991): monohrafiya. Lviv: Vydavnytstvo Lvivskoyi politekhniky, 164 s. (In Ukrainian).

Yulian Zakharievych: [prof. arkhit., rektor (1877-1878, 18811882 rr.)] (2009). In: Bobalo, Yu. Ya., Zahorodniy, A. H. (ed.). Natsionalnyi universytet "Lvivska politekhnika": istorychne vydannia. Kyiv: Lohos Ukraina, S. 29 (In Ukrainian).

Yulian-Oktavian z mista Leva Zakharievych (2004). In: Rudavskyi, Yu. K. (ed.). Natsionalnyi universytet "Lvivska politekhnika": yuvil. vyd. do 160-richchya. Lviv: Vyd-vo Nats. un-tu "L'viv. politekhnika", S. 27-28 (In Ukrainian). 
Zajączkowski, W. C. K. (1894). Szkoł a Politechniczna we Lwowie: rys historyczny jej zał ożenia i rozwoju, tudzież stan jej obecny. Lwów: Nakł. Szkoły Politechnicznej, S. 95, 102 (In Polish).

Zakharevych Yulian Oktavian: [prof. kaf. arkhit., rektor Lviv. politekhiky (1877-1878, 1881-1882 rr.)] (2004). In: Vasylenko, L. S., Voytovych, M. V., Hubenko, V. M. ta in. (compiler). Lvivshchyna ta Ivivyany: entsykloped.-biohr. dovid. Lviv: VIKA, S. 410. (Novitnya istoriya Ukrayiny; vyp. 1) (In Ukrainian).

Zhuk, O. (2007). Profesor arkhitektury Yulian Zakharievych. Arkhitekturnyi visnyk. № 3/4 (33). S. 50-53. (In Ukrainian).

Zhuk, O. K. (2002). Z istoriyi budivnytstva holovnoho korpusu Lvivskoyi politekhniky. Arkhitekturnyi visnyk. № 3-4 (16). S. 50 53 (In Ukrainian).

Zhuk, O. K. (2004). Do 160-richchya Lvivskoyi politekhniky. in: Deshchynskyi, L. Ye. (ed.). Derzhava ta armiya: zbirnyk naukovykh prats. Lviv: Vyd-vo Nats. un-tu "Lviv. politekhnika", S. 141145 (In Ukrainian).

Zhuk, O. K. (2004). Holovna budivlya Lvivskoyi politekhniky: do 160-richchya Nats. un-tu "Lviv. politekhnika". Lviv: Vyd-vo Nats. un-tu "L'viv. politekhnika", 75 s. (In Ukrainian).

Zhuk, O. K. (2006). Holovna budivlya Lvivskoyi politekhniky: do 160-richchya Natsionalnoho universytetu "Lvivska politekhnika". 2-he, dopov., pererobl. Lviv: Vyd-vo Nats. un-tu "Lviv. politekhnika", $78 \mathrm{~s}$. (In Ukrainian).

Zhuk, O. K. (2008). Holovna budivlya Lvivskoyi politekhniky. vyd. 2-he, zi zminamy i dopov. Lviv: Vyd-vo Nats. un-tu "Lviv. politekhnika", 76 s. (In Ukrainian).

Zhuk, O. K. (2008). Mystetstvo dyzaynu u tvorchosti Yuliana Zakharievycha. In: Cherkes, B. S. (ed.). Arkhitektura: zbirnyk naukovykh prats. Lviv: Vyd-vo Nats. un-tu "Lviv. politekhnika", S. 216-218. (Visnyk / Nats. un-t "Lviv. politekhnika"; № 632) (In Ukrainian).

\section{LIST OF REFERENCE LINKS}

Kubelik M. Das k.k. Polytechnische Institut in Wien zur Zeit des Studenten Julian Zachariewicz. Архітектура Галичини XIX-XX cm.: вибр. матеріали міжнар. симп., 24-27 трав. 1994 р., Львів: присвяч. 150-річчю заснування Держ. ун-ту "Львів. політехніка" / за ред. Б. Черкеса, М. Кубеліка, Е. Гофер. Львів: Вид-во Держ. ун-ту "Львів. політехніка", 1996. С. 89-98.

O budowie gmachów c. k. Szkoły Politechnicznej we Lwowe. Dźwignia. 1877. № 5. S. 35-36.

Politechnika Lwowska 1844-1945. Wrocław: Wyd-wo Politechniki Wrocławskiej, 1993. S. 19-22, 29, 51, 139, 143-144, 155, 173, 194, 195, 202, 203.

Politechnika Lwowska: jej stan obecny i potrzeby. Lwów, 1932. S. 108-109.

Popławski Z. Dzieje Politechniki Lwowskiej, 1844-1945. Kraków: Zakł. Nar. im. Ossolińskich, 1992. S. 54, 58, 62, 66-68, 72, 73, 77, 96, 97, 102-105, 111, 116, 117, 302, 306.

S.p. Zachariewicz Julian Oktawian: nekrolog. Czas. Techn. 1899. Rocz. 17, № 1. S. 1-3.

Uroczyste odsłonięcie pomnika ś. p. [świętej pamięci] Juliana Zaharjewicza. Gazeta Lwowska. 1910. 13 wrześ. (№ 207). S. 4

Zajączkowski W. C. K. Szkoła Politechniczna we Lwowie: rys historyczny jej założenia i rozwoju, tudzież stan jej obecny. Lwów: Nakł. Szkoły Politechnicznej, 1894. S. 95, 102.

Архітектура Львова. Час і стилі XIII-XXI ст. / М. Бевз, Ю. Бірюльов, Ю. Богданова, В. Дідик, У. Іваночко, Т. Клименюк, Х. Ковальчук, Ю. Криворучко, С. Лінда, Т. Максим'юк, Р. Мих, Р. Могитич, І. Оконченко, Г. Петришин, Б. Посацький, О. Рибчинський, І. Сварник, Р. Франків, Б. Черкес. Львів: Центр Європи, 2008. С. 51, 52, 140, 247-249, 256, 266, 267, 290, 294, 300, $303,306,310,318,346,347,349,351,353,354,356,375,391$, 392, 396, 407, 411, 457, 477.

Бірюльов Ю. Захаревичі творці столичного Львова. Львів: Видавництво "Центр Європи", 2010. 336 с.
Буцко М. Захаревич Юліан Октавіан. Буцко М. І. Відомі вчені Державного університету "Львівська політехніка". 1844-1994: біогр. довід. Львів: Вид-во Держ. ун-ту "Львів. політехніка", 1994. С. 58-59.

Буцко М. І., Кипаренко В. Г. Державний університет "Львівська політехніка" 1844-1994. Львів: Вид-во Держ. унту "Львів. політехніка", 1994. Із змісту: про Ю. Захарієвича. С. $5,9,10,13,19,90$.

Буцко М. Юліан Захаревич: [ректор Львів. політехніки (1877-1878, 1882-1883 рр.)]. Рад. студент. 1988. 31 груд. (№ 38). С. 4.

Грицак Я. Пророк у своїй вітчизні. Франко та його спільнота (1856-1886). Київ: Критика, 2006. С. 545.

Жук О. К. Головна будівля Львівської політехніки. вид. 2-ге, зі змінами і допов. Львів: Вид-во Нац. ун-ту "Львів. політехніка", 2008. 76 с.

Жук О. К. Головна будівля Львівської політехніки: до 160річчя Нац. ун-ту "Львів. політехніка". Львів: Вид-во Нац. унту "Львів. політехніка", 2004. 75 с.

Жук О. К. Головна будівля Львівської політехніки: до 160річчя Національного університету "Львівська політехніка". 2-ге, допов., переробл. Львів: Вид-во Нац. ун-ту "Львів. політехніка", 2006. $78 \mathrm{c}$.

Жук О. К. До 160-річчя Львівської політехніки. Держава та армія: зб. наук. пр. / відп. ред. Л. Є. Дещинський. Львів: Вид-во Нац. ун-ту "Львів. політехніка", 2004. С. 141-145.

Жук О. К. 3 історії будівництва головного корпусу Львівської політехніки. Архітектур. вісн. 2002. № 3-4 (16). С. 50-53.

Жук О. К. Мистецтво дизайну у творчості Юліана Захарієвича. Архітектура: зб. наук. пр. / відп. ред. Б. С. Черкес. Львів: Вид-во Нац. ун-ту "Львів. політехніка", 2008. С. 216218. (Вісник / Нац. ун-т "Львів. політехніка"; № 632).

Жук О. Професор архітектури Юліан Захарієвич. Архітектур. вісн. 2007. № 3/4 (33). С. 50-53.

Захаревич Юліан Октавіан: [профф. каф. архіт., ректор Львів. політехіки (1877-1878, 1881-1882 рр.)]. Львівщина та львів'яни: енциклопед.-біогр. довід. / упоряд.: Л. С. Василенко, М. В. Войтович, В. М. Губенко та ін. Львів: ВІКА, 2004. С. 410. (Новітня історія України; вип. 1).

Капраль М. Національні громади Львова XVI-XVIII ст. (соціально-правові взаємини). Львів: ЛНУ ім. І. Франка, Львівське відділення Інституту української археографії та джерелознавства ім. М. С. Грушевського НАН України, 2003. С. 178-190.

Кисілевський В. Ю. Статистичний опис Галичини у 1840 році. Український історик [Мюнхен]. 1965. № 1-2. С. 46-48.

Клименюк Т. Педагогічна діяльність Ю. Захаревича, традиції Львівської архітектурної школи. Техн. вісті / Укр. інж. $m$-во. 2000. № 1(10), 2(11). С. 86-91.

Липка Р. Львівська архітектурна школа - їі роль та етапи розвитку: [про архітектур. фр-т Львів. політехніки, Ю. Захарієвича]. Техн. вісті / Укр. інж. m-во. 2000. № 1(10), 2(11). С. 99-110.

Лонкевич І. Сповідував і творив красу: [про ректора Львів. політехніки Юліана Захарієвича]. Аудиторія. 1998. 18-30 груд. (чис. 45-46). С. 7.

Монолатій І. С. Галицько-буковинські сюжети в історії вірменської діаспори Габсбурзької монархії: спроба (ре)конструкції. Прикарпатський національний університет імені Василя Стефаника. URL: http://ekmair.ukma.edu.ua/bitstream/handle/ 123456789/7169/Monolatiy_Halytsko_bukovynski_syuzhety.pdf?sequence $=1$ \&isAllowed $=y$.

Odezwa: [про встановлення бюста Ю. Захарієвича у головному корпусі Львів. політехніки]. Czas. Techn. 1909. Rocz. 27, № 2. S. 13, 122.

Петровська Ю. Синтез мистецтв у творчості архітекторів Львівської архітектурної школи зламу XIX-XX ст.: [про Ю. Захарієвича, І. Левинського, Т. Тальовського, В. Садловсь- 
кого, Т. Обмінського]. Геодезія, архітектура та будівництво: матеріали IV Міжнар. конфр. молодих вчен. GAC-2011, 2426 листоп. 2011 р., Україна, Львів / Нац. ун-т "Львів. політехніка". Львів: Вид-во Львів. політехніки, 2011. С. 32-35.

Пиотровская И. Д. Биографика: введение в науку и обозрение источников биографических сведений о деятелях России 1801-1917 гг. Изд. 2-е, испр. и доп. СПб.: Петрополис, 2010. 384 c.

[Про Юліана Захарієвича]. Аудиторія. 2008. 23-29 жовт. (чис. 30). С. 4

Садовська Є. Я. Юліан Октавіан Захарієвич - реставратор костьолів. Архітектура: зб. наук. пр. / відп. ред. Б. С. Черкес. Львів: Вид-во Нац. ун-ту "Львів. політехніка", 2002. С. 122-127. (Вісник / Нац. ун-т "Львів. політехніка"; № 439).

Хенрик Дитхен. Львівська політехніка у Львові: історія технічного університету у багатонаціональному середовищі. Штутгарт, 2015.

Черкес Б. Вступ. Звідки і куди: архітектура Галичини XIXXX століть: [про Ю. Захарієвича]. Архітектура: зб. наук. пр. / відп. ред. Б.С. Черкес. Львів: Вид-во Нац. ун-ту "Львів. політехніка", 2007. С. 19-44.

Черкес Б. Основоположник: [про засн. архітектур. школи Львів. політехніки, ректора (1877-1878, 1881-1882 рр.) Юліа-

на Захарієвича]. Львів. політехнік. 1994. Травень (спец. вип.). C. 6 .

Черкес Б. С., Жук О. К. Юліан Захарієвич - основоположник львівської архітектурної школи. Архітектура: зб. наук. пр. / відп. ред. Б.С. Черкес. Львів: Вид-во Нац. ун-ту "Львів. політехніка", 2007. С. 163-167. (Вісник / Нац. ун-т "Львів. політехніка"; № 585).

Юліан Захарієвич: [проф. архіт., ректор (1877-1878, 18811882 рp.)]. Національний університет "Львівська політехніка": icm. вид. / редкол.: Ю. Я. Бобало (голова), А. Г. Загородній (заст. голови), В. А. Павлиш, З. Г. Піх, Я. О. Величко, Р. Д. Зінкевич, А. І. Кос, М. А. Серб. Київ: Логос Україна, 2009. C. 29.

Юліан-Октавіан з міста Лева Захарієвич. Національний університет "Львівська політехніка": ювіл. вид. до 160-річчя / відп. ред. Ю. К. Рудавський; редкол.: П. Костробій, В. Павлиш, А. Загородній та ін. Львів: Вид-во Нац. ун-ту "Львів. політехніка", 2004. С. 27-28.

Яворський В., Блажівський К. Історія хімічної, хіміко-технологічної освіти і науки у Львівській політехніці (1844-1991): монографія. Львів: Видавництво Львівської політехніки, 2001. $164 \mathrm{c}$.

Левик Богдан,

Національний університет "Львівська політехніка" (м. Львів, Украӥна)

e-mail: levykbs@gmail.com,ORCID:0000-0001-5100-0834

\section{ЛЬВІВСЬКІ ЗДОБУТКИ ВІРМЕНИНА ЮЛІАНА ОКТАВІАНА ЗАХАРІЕВИЧА}

У рам ках дослідження теми "Видатні особистості у культурі та розбудові Львова" простежено життєвий шлях талановитого архітектора-вірменина Юліана Октавіана Захарієвича (17.07.1837 - 27.12.1898 рр.), який присвятив себе науковій та педагогічній діяльності у Львівській політехніці, тодішній Імператорсько-королівській політехнічній школі. Заснувавши Галицьку архітектурну школу, він зумів реалізувати свої проекти в адміністративних і приватних будівлях Львова та коронного краю Галичини і Володимірії (Лодомерії), що залишаються прикрасою і зразком архітектурної майстерності до цих пір. У рамках дослідження автор уводить в науковий обіг газетні публікації минулих років (дорадянський період, вересень 1939 р.), присвячені урочистим датам, пов'язаним з іменем видатного архітектора. Автор робить висновок, що біографію Юліана Захарієвича можна розглядати як історичне джерело дослідження розвитку архітектури стилю "нео" в адміністративних, сакральних, приватних міських забудовах Львова в австро-угорський період (1872-1918 рр.). Попри те, що Захарієвич сам не акцентував увагу на своїй національній приналежності, його зв'язки з вірменською діаспорою, вірменським етносом та вірменським християнством відбиваються на його творчості і цей аспект має бути досліджений у майбутньому.

Ключові слова: Захарієвич Юліан Октавіан; Технічна академія у Львові; Львівська вища технічна школа; Цісарсько-королівська політехнічна школа; Національний університет "Львівська політехніка".

(C) Levyk Bohdan

Надійшла до редакції: 05.03.2019

Прийнята до друку: 17.04.2019 